\title{
RATING CONTROL IN LEARNING TO RUSSIAN AS A FOREIGN LANGUAGE
}

\author{
Anna Alexandrovna Erofeeva \\ Kazan Federal University, Kazan, Russia \\ Tatyana Alexandrovna Korneyeva \\ Kazan Federal University, Kazan, Russia \\ Tatyana Damirovna Markova \\ Linguistics University of Nizhny Novgorod, Russia \\ E-mail: tatyana.tak1110@gmail.com
}

Recepción: 05/08/2019 Aceptación: 16/09/2019 Publicación: 23/10/2019

\section{Citación sugerida:}

Erofeeva, A.A., Korneyeva, T.A. y Markova, T.D. (2019). Rating control in learning to Russian as a foreign language. 3C TIC. Cuadernos de desarrollo aplicados a las TIC. Edición Especial, Octubre 2019, 194-205. doi: https://doi.org/10.17993/3ctic.2019.83-2.194-205

Suggested citation:

Erofeeva, A.A., Korneyeva, T.A. \& Markova, T.D. (2019). Rating control in learning to Russian as a foreign language. 3C TIC. Cuadernos de desarrollo aplicados a las TIC. Special Issue, October 2019, 194-205. doi: https://doi.org/10.17993/3ctic.2019.83-2.194-205 


\section{ABSTRACT}

The urgency of the research is in seeking for the methods and techniques to intensify the learning activities of students in learning to Russian as a foreign language, to increase their motivation, to develop creative potential, mutual help and cooperativeness in a classroom environment and outside the classroom. One of the effective methods for improving learning is the rating control of the educational activities of students. This article is supposed to substantiate the effectiveness of the systematic use of rating control and ranking students at each stage of the Russian language learning as foreign. The basic research methods are the modeling of study process, the methods of analysis and synthesis, lesson observation, experiment (diagnostic, prognostic, organizational, practical, generalizing). The results of the study show the effectiveness of applying systematic ranking of the students within the classes following on from the results of the educational task, the effectiveness of the model of classes in Russian as a foreign language in which a student who occupies the highest position in the ranking is always first to be tested. The study of the impact of rating control system in teaching Russian as a foreign language on student performance and increasing their level of language competence plays an important role in improving the methods and techniques of organizing educational work in Russian.

\section{KEYWORDS}

Russian as a Foreign Language, Methods, Control, Rating, Ranking. 


\section{INTRODUCTION}

Differentiation in teaching and an individual approach to students in the process of teaching of Russian as a foreign or non-native language often leads to an underestimation of the competitive factor in teaching and the orientation of teachers to "average" students or low-performing students. This reflects a bad effect on the educational process and personal achievements of students. Meanwhile, the focus of the teaching methodology and didactic material on highachieving students allows making great educational progress and stimulating the educational and cognitive activity of all students in the training group, regardless of the level of competence in a discipline. A similar system for organizing educational activities of students in Russian as a foreign language is based on a constant ranking of students in terms of the quality and efficiency of learning activity.

One of the effective methods for generating a higher return from education is the rating control of learning activity of the students. Rating is generally understood as an individual numerical indicator of an evaluation of attainments in studies. It is obtained by adding the rating marks obtained as a result of the assessment of individual educational activities, if possible, considering the coefficient of significance ("weight" coefficient) of these actions in achieving educational goals (Chernyavskaya \& Grechin, 2008). The main principle of rating is ranking. Rating learning technology enables to obtain objective data on the level of student's grades. The scientific literature differentiates the cumulative ratings Olympic, leadership, certificate ratings - from the academic achievement ratings (Chernyavskaya \& Grechin, 2008). The grades for the first three ratings are cumulated during the last years of schooling and are extended to the next year. The ranking of academic achievements summarizes the grade point average of all academic disciplines. Thus, rating control is one of the modern means of assessing the quality of education and is applied, as a rule, at the final stages of training, when it is necessary to differentiate the students in order to distribute them among subject major or academic classes. Institutions of higher learning 
use the system of rating control more consistently in the form of a grade-rating system to assess the quality of students' academic work using block-modular learning technology (Arkayeva, 2009).

Rating control in the system of learning to Russian as a foreign language has not been practically studied. As a rule, scientific works dealing with the methods of learning to Russian as a foreign language discuss the system for testing foreign students and methods for the development of control and test materials for various levels (Balykhina, 2007). Koryakina (2017) in her work considers the functions of control (verification, training, developmental, educational), the types of control (preliminary, current, mid-term, final), the methods (written assignments and tests) and the forms of control (individual and frontal). The importance of using all types of control in teaching of a foreign language is noted (Koryakina, 2017). However, the actual rating control has remained out of eyeshot of the scholar.

From our point of view, the essence of rating control in the methodology of learning to Russian as a second language lies primarily in the constant ranking of the results of students performing learning tasks. On this basis an effective model of classes in Russian as a foreign language is built, according to which a student who occupies the highest position in the ranking is always first to be tested. This means that the teacher starts marking test of the student who completed the previous task best and then in descending order. We should pay attention to the mobility of the rating within one lesson and in learning overall. The students' ranking is built upon the completion of a concrete task, and during the lesson the student's place in the ranking can be changing. The main condition is that the student who is the first to have performed the previous task speaks, then according the place in the ranking. With such an organization of the control system, considerable attention is paid to high-achieving learners. Low-performing students get additional opportunities to recognize by listening and solidify the knowledge to have been acquired and demonstrate certain success in learning. 


\section{METHODOLOGY}

The main research methods include: theoretical analysis of scientific and educational literature, modeling of the learning process, methods of analysis and synthesis, lesson observation, experiment (diagnostic, prognostic, organizational, practical, generalizing), conversation method. The study of specialized literature on the topic made it possible to identify the main methods and techniques used in learning to Russian as a foreign language, focus on communicative teaching technologies, especially the interaction with the students during the lesson (Safonova \& Lukoyanova, 2016; Fazliakhmetov \& Yusupova, 2018; Rakhimova et al., 2017), organize a problem-based dialogue (Fattakhova et al., 2018), study the history of the issue (Safonova \& Erofeeva, 2017; Andrade, 2017). Modeling of the learning process made it possible to identify learning strategies and tactics, predict student behavior, and optimally organize the educational process. Lesson observation made it possible to collect factual material and analyze the learning outcomes. Using the methods of analysis and synthesis, the results of experiments have been summarized and analyzed, and an idea about the further improvement of the learning process have been formed. The experimental method made it possible to trace changes in the quality of knowledge and skills of students following from the result of using the rating control technique. The method of conversation contributed to the identification of psychological characteristics of students and the impact on them of the above learning system.

\section{RESULTS AND DISCUSSION}

The testing of the rating control methods in class on Russian as a foreign language was carried out based on the Kazan (Privolzhsky) Federal University during the 2017-2018 and 2018-2019 academic years in the groups of students from Xi'an Petroleum University (China) who were undergoing internship in Russian at the department Russian language and its teaching methods. The average age 
of the students was 20 years, the time of studying the Russian language before arriving in Kazan was two years, the time of studying at KFU was eight months (excluding winter holidays).

Testing was carried out in two stages. The first stage (diagnostic, prognostic, organizational, practical stages of the experiment) is the academic year 20172018, one group (12 people), courses on practical grammar of the Russian language and improvement of written language. The second stage (practical, generalizing the stages of the experiment) - the academic year 2018-2019, one group (12 learners) - the courses on practical grammar of the Russian language, on improving written language (eight months), on morphology (four months); two groups (11 and 12 learners) - morphology (four months).

During the first stage of testing based on observation methods and primary control methods, the psychological and pedagogical features of a group of Chinese learners of a specified age and their level of knowledge of the Russian language which turned out to be quite low, as well as a high level of motivation and interest in the learning process, were revealed. Based on the obtained psychological and pedagogical results and considering the individual capabilities of students, it was decided to use the methods of rating control of the results of students' attainment at each stage of the lesson on the above courses. Then, during the four months of training, the teacher began to grade each performed task of the student who completed the previous task best, and then in descending order. The ranking of students was built upon the completion of a certain task, and during the lesson the student's rank could repeatedly change. The students' rating was mobile within the same lesson and in the study overall. The main condition was that the student who took the previous assignment best to speak first, then according to the ranking. With such an organization of classes, considerable attention was paid to the advanced students. The weaker students received additional opportunities to recognize by listening and solidify the studied material and demonstrated concrete success in learning. When changing the place in the ranking, as a rule, the sequence of positions of two learners changed, less often - of three ones. 
In the process of teaching practical grammar and improving the written language of the students, all types of speech activities were involved: reading, writing, listening, speaking, but the priority was given to speaking, that is, to developing skills in the possession of grammatical material in oral form (based on a communicative technique).

Significant conditions for implementing the proposed model were: a) a high pace of the lesson, b) an obligatory testing of all students in the group, c) the time limit for an answer (3-5 minutes on average), d) putting grades for each completed assignment and announcing the results to the students (at the end of the lesson).

Testing of the methodology showed significant achievements of a group of trainee students in four months and an increase in the level of formation of language competence.

The negative aspects of testing the systematic ranking of students by the level of assignments to be performed in the academic year of 2017-2018 should include: 1) psychological discomfort of the student who is always the last on the list; 2) gradually forming psychological fatigue of the group as a result of intensive educational activities. To reduce the negative consequences of studying in the second semester (the next four months), a system of encouraging tasks for low-performing students (a variety of creative tasks that helped them realize their potential and improve speech quality) was devised and a group work with account taken of the interaction of advanced and weaker students (dialogs, mutual testing, mutual control, etc.) was organized. However, the basic principle of rating control and ranking was retained.

During the second stage of testing in the academic year of 2018-2019, the methods and techniques for organizing learning activities of foreign students and the system for organizing rating control (with application of the basic principles) were improved. When analyzing the learning outcomes of students in the group in which the ranking system was tested, a significantly higher level of formation of language competence (especially in speaking) was observed with other groups in the study group. It is characteristic that the inclusion of two other groups in the 
experiment at the beginning of the second semester in the course of morphology also showed a significant intensification of students' learning activity and the improvement of all types of speech activity. At the stage of 2018-2019, there were no negative effects in the form of psychological fatigue of the group or psychological discomfort of the weakest student.

As a result of testing, a learning model focused on advanced students, while studying the practical grammar of the Russian language and improving written language, significant successes of all students of the foreign group of students studying the Russian language, their interest in the final learning results, cooperativeness and mutual help were noted. This has confirmed the assumptions by the scholars of Kazan University in several works dealing with the peculiarities of teaching foreign students to the Russian language (Safonova \& Lukoyanova, 2016; Fazliakhmetov \& Yusupova, 2018; Rakhimova et al., 2017; Fattakhova et al., 2018; Safonova \& Erofeeva, 2017). The interest in learning the Russian language, the desire to take a higher position in the ranking, the obvious results of successful educational activities motivate the students who are learning Russian to learn it further.

\section{SUMMARY}

Thus, the following should be attributed to significant research results. 1) The necessity of a scientific description of the rating control system in learning to Russian as a foreign language has been substantiated. 2) The effectiveness of the systematic ranking of students in the classroom based on the results of the educational task has been proved. 3) The effectiveness of the model of classes in Russian as a foreign language has been proved, in which a student who occupies the highest position in the ranking is always first to be tested. 4) The need for objectivity in assessing the knowledge and skills of the students, the strictness and at the same time goodwill of the teacher, an elaborated system of moral encouragement of the participants in the learning process has been emphasized. 5) Attention is drawn to the mobility of rating within one lesson and in training 
overall. The ranking of students is built upon the completion of a concrete task, and during the lesson the student's place in the ranking can repeatedly change. The main condition is that the student who is the first to perform the previous task speaks first, then according to the ranking. 6) It has been revealed that with such an organization of the control system, considerable attention is paid to highperforming students. Low-performing students receive additional opportunity to recognize the material by listening and solidify it and demonstrate certain success in learning. 7) Important conditions for the implementation of the model are: a) a high pace of the lesson, b) an obligatory testing of all students in the group, c) the time limit for an answer (3-5 minutes on average), d) putting grades for each completed assignment and announcing the results to the students (at the end of the lesson). 8) The stimulating effect is the pair and group work of the students, challenging tasks.

\section{CONCLUSIONS}

Even though the methods of learning to Russian as a foreign language has been developed quite comprehensively and in detail, the questions concerning the intensification of learning activities of students and the maintenance of their interest in the subject have been remained within eyeshot of methodological scientists so far. In this respect, the methods of rating control and ranking the learners according to the results of their learning activities deserves attention and requires having been further researched and tested in the context of other disciplines of learning to Russian as a foreign language.

\section{ACKNOWLEDGMENTS}

The work is performed according to the Russian Government Program of Competitive Growth of Kazan Federal University. 


\section{REFERENCES}

Andrade, M. S. (2017). Institutional Policies and Practices, and Tracking International Students. Fournal of international students, 7(1), 1-6.

Arkayeva, R. P. (2009). The Qualimetrical approach in quality management of formation of students. Vestnik Severo-osetinskogo Gosudarstvennogo Universiteta imeni K.L.Khetagurova-Bulletin of the North-ossetian State University named after C.L.Khetagurov, Vladikavkaz, Severo-osetinskiy Gosudarstvennyi Universitet, 3, 44-46.

Balykhina, T. M. (2007). Methods of teaching Russian as a non-native (new). Moscore, Izdatel'stvo Rossiyskogo universiteta druzhby narodov, 185 p.

Chernyavskaya, A. P., \& Grechin, B. S. (2008). Modern means of evaluating learning outcomes. Vestnik Yaroslavskogo Gosudarstvennogo Pedagogicheskogo Universiteta imeni K.D. Ushinskogo-Bulletin of the Yaroslavl State Pedagogical University named after KD Ushinsky, Taroslavl, Taroslavskiy Gosudarstvennyy Pedagogicheskiy Universitet, 9, 98.

Fattakhova, N., Faizullina, N., \& Mubarakshina, A. (2018). Teacher and student relation in a dialogue. Modern Fournal of Language Teaching Methods, 8(12), 743-755.

Fazliakhmetov, I., \& Yusupova, Z. (2018). Methodological heritage of Kazan scientists in the field of teaching the Russian language. IIOAB FOURNAL, 9, 174176.

Koryakina, A. V. (2017). Point-rating system as a means of assessing the formation of competencies. Scientific and methodical electronic journal "Concept"Scientific and methodical electronic journal "Concept", Moscore, Izdatel'stvo MTSITO, 25, 216-219.

Rakhimova, D., Ghernysheva, A., \& Komar, N. (2017). Speech-behavioral tactics of apologi in secular and religious cultures. Ad Alta-journal of interdisciplinary research, 7(2), 190-192. 
Safonova, S. G., \& Erofeeva, I. V. (2017). Conceptual opposition "friend enemy" in Russian medieval period. Astra Salvensis, 5(10), 199-204.

Safonova, S. G., \& Lukoyanova, Y. K. (2016). The teaching of speech etiquette in the course of Russian as a foreign language. Modern fournal of Language Teaching Methods (MFLTM), Special Issue (December 2016), 81-85. 